\title{
Importance of bioturbators for biodiversity maintenance: indirect effects of fishing disturbance
}

\author{
Stephen Widdicombe ${ }^{1, *}$, Melanie C. Austen ${ }^{1}$, Michael A. Kendall ${ }^{1}$, Frode Olsgard $^{2,3}$, \\ Morten T. Schaanning ${ }^{2}$, Sarah L. Dashfield ${ }^{1}$, Hazel R. Needham ${ }^{1}$ \\ ${ }^{1}$ Plymouth Marine Laboratory, Prospect Place, West Hoe, Plymouth PL1 3DH, UK \\ ${ }^{2}$ Norwegian Institute for Water Research, PO Box 173, Kjelsaas, 0411 Oslo, Norway \\ ${ }^{3}$ Section of Marine Biology and Limnology, Department of Biology, University of Oslo, PO Box 1064, Blindern, 0316 Oslo, Norway
}

\begin{abstract}
The relative impact on macrofaunal diversity of 7 naturally co-occurring bioturbators has been examined in a benthic mesocosm experiment. The bioturbators chosen were selected because of their potential vulnerability to the disturbances associated with demersal trawling. The experiment was conducted at the Solbergstrand mesocosm (Norwegian Institute for Water Research) using subtidal sediment collected from Bjørnehodebukta, a small sheltered bay in the Oslofjord. For 3 of the bioturbating species (Brissopsis lyrifera, Aphrodita aculeata and Amphiura chiajei) a positive, linear relationship was demonstrated between bioturbator abundance and measures of species richness (number of species and Margalef species richness). It was suggested that the presence of these bioturbating species increased oxygen penetration into the sediment, leading to an enhancement in the ability of benthic systems to process organic material. This had a beneficial effect on the associated fauna in terms of maintaining levels of diversity. For Nephtys caeca, highest species diversity was seen in the low abundance treatments. Predation by N. caeca on small polychaetes is proposed as a possible explanation of the lower diversity in high-density treatments. It is concluded that $B$. lyrifera, A. aculeata, A. chiajei and N. caeca are functionally similar with respect to setting the diversity of the associated macrobenthic community and may therefore fulfill the same role within the benthic ecosystem. The presence of Calocaris macandreae, Nuculana minuta and Astarte sulcata had no detectable effect on diversity. Trawling has been shown to reduce the abundance of bioturbating species, and the current study demonstrates important implications of this loss on the maintenance of diversity. In addition, the interactions between bioturbation, diversity and organic enrichment highlight the need for management of anthropogenic impacts within the coastal environment in a holistic way rather than by isolation.
\end{abstract}

KEY WORDS: Diversity - Macrofauna - Bioturbation · Trawling · Disturbance · Mesocosm . Eutrophication · Oslofjord

\section{INTRODUCTION}

The disturbances associated with benthic trawling have widespread impacts on soft sediments and the communities that inhabit them (Rijnsdorp et al. 1998). A large number of studies have been conducted to assess these impacts (e.g. Jennings \& Kaiser 1998, Frid et al. 1999, Jennings et al. 2002) and most have reported a shift from a highly diverse community with large-bod- ied animals and a large number of tube-builders in undisturbed areas to communities dominated by smallbodied species, particularly polychaetes, in places that are heavily trawled. A significant depletion of megafauna (large [>10 mm] epifauna or infauna) following trawling has also been demonstrated by a number of authors (De Groot \& Lindeboom 1994, Hill et al. 1996, Kaiser et al. 1996, 1998). Megafaunal species are particularly vulnerable because they are typically long- 
lived and take a relatively long time to reach a reproductive age (e.g. Buchanan 1964, 1967, Fenaux 1970, Munday 1992). Such reproductive strategies mean that any impact on the population of these species may still be evident years after the fishing disturbance occurred. In such circumstances even moderate fishing might reduce or destroy megafaunal populations.

As megafaunal species feed and move, they inevitably disturb the fabric of the sediment; a disturbance known as bioturbation. These bioturbating species, such as burrowing shrimps and echinoids, are instrumental in setting and maintaining infaunal diversity in soft-sediment environments (Widdicombe et al. 2000). Experimental evidence to support this has been provided from both field- and laboratory-based studies, which have demonstrated strong links between individual bioturbating species and their associated communities (e.g. Posey 1986, Warwick et al. 1986, 1990, Posey et al. 1991, Widdicombe et al. 2000). Whilst the primary effects of trawling, such as the direct mortality of species due to damage from the fishing gear, has been well studied (e.g. Jennings \& Kaiser 1998, Frid et al. 1999, Jennings et al. 2002), the secondary effects of trawling, in particularly the removal of bioturbating organisms, is less well understood.

On mixed substrata, the passage of a trawl can destroy structural species such as anemones, bryozoans and sponges and, in doing so, degrade the spatial complexity of the habitat (Tupper \& Boutilier 1995). This in turn has been shown to reduce the survivorship of juvenile commercial fish species (Tupper \& Boutilier 1995). The presence of epifaunal, structural species in mixed substrata is visually apparent, making it easy to appreciate the increased complexity that such species add to the habitat. In softer sediments, where the majority of organisms live below the surface, the habitat heterogeneity and 3-dimensional structuring provided by the bioturbators (Widdicombe et al. 2000) is not so immediately obvious. It is conceivable that, for the maintenance of spatial complexity, losing large bioturbators from muddy areas may be equivalent to losing epifaunal species such as bryozoans and sponges from areas of coarser, mixed sediment.

Using a manipulative mesocosm experiment, the sediment and associated macrofauna from an untrawled site were subjected to the different types of bioturbation generated by 7 naturally co-occurring infaunal bioturbators. The bioturbators chosen are potentially vulnerable to trawling and the experiment examined their relative impact on diversity. By carefully controlling the type and density of bioturbators present, this study explored the potential implications on the associated macrofauna of bioturbator loss due to trawling. This is the first attempt to directly compare such a large number of bioturbators at a range of realistic field densities.

\section{MATERIALS AND METHODS}

Bioturbating species. The 7 species of bioturbators selected for this study were Brissopsis lyrifera, Nuculana minuta, Calocaris macandreae, Amphiura chiajei, Nephtys caeca, Aphrodita aculeata and Astarte sulcata. These species were chosen as they represent a range of bioturbation mechanisms, are potentially vulnerable to fishing, and are abundant in the Oslofjord.

The burrowing heart urchin Brissopsis lyrifera (Forbes, 1841) is a non-selective, infaunal deposit-feeder (Nichols 1959) which can burrow to a depth of $10 \mathrm{~cm}$ and is known to ingest both surface and deep sediment (Lawrence 1987). By 'bulldozing' through the sediment, it has a major impact on sediment structure and stability. In addition, by creating a respiratory funnel in the upper $3 \mathrm{~cm}$ of sediment (De Ridder \& Lawrence 1982), $B$. lyrifera increases the depth of oxygenation. The presence of this species has been shown to enhance both local heterogeneity and diversity in a macrobenthic community (Widdicombe \& Austen 1998).

The bivalve Nuculana minuta (Müller, 1776) is also a subsurface 'bulldozing' deposit feeder and it may, therefore, be expected that bioturbation caused by this species and that caused by Brissopsis lyrifera will have similar effects on diversity. However, B. lyrifera (max. length $6 \mathrm{~cm}$ ) is a much larger organism than $N$. minuta (max. length $3 \mathrm{~cm}$ ), it moves faster and, consequently, its movements will displace more sediment and any response in diversity to its bioturbation may differ in magnitude from that seen for $N$. minuta.

The thalassinidean shrimp Calocaris macandreae (Bell, 1846) constructs deep, complex burrows with multiple surface openings (Nash et al. 1984). These shrimps rarely emerge onto the sediment surface, obtaining the majority of their food from within the burrow; subsurface sediment from as deep as $215 \mathrm{~mm}$ may be expelled during normal feeding activities and burrow maintenance (Nash et al. 1984).

The brittlestar Amphiura chiajei (Forbes, 1843) lies buried in the sediment with its disc at 4 to $6 \mathrm{~cm}$ depth, with 1 or 2 arms stretched up above the sediment to collect food at the surface. Food particles are then transported along the arms to its mouth, and ingested (Buchanan 1964). Other arms may be extended deeper into the sediment below the disc. A. chiajei is particularly slow-growing, with a typical increase in disk diameter of $0.25 \mathrm{~mm} \mathrm{yr}^{-1}$ compared to $1.6 \mathrm{~mm} \mathrm{yr}^{-1}$ for the closely related species $A$. filiformis (Buchanan 1964).

The burrowing polychaete Nephtys caeca (Fabricus, 1780) is a large, predatory worm, 15 to $25 \mathrm{~cm}$ long, that creates non-permanent burrows, marked only by mucilage lining, as it moves through the sediment in search of food. This species is highly mobile and will 
create sediment mixing to a depth in excess of $15 \mathrm{~cm}$. This species lives for up to $15 \mathrm{yr}$ (Caron et al. 1995).

Aphrodita aculeata (L., 1758) is a large (up to $20 \mathrm{~cm}$ long), oval-bodied polychaete worm. It is an active, mobile predator (Mettam 1980) but, unlike Nephtys caeca, this species operates close to or actually on the sediment surface.

Astarte sulcata (da Costa, 1778) is a medium-sized (shell length up to $3 \mathrm{~cm}$ ), suspension-feeding bivalve that remains near the sediment surface with the upper edge of its shell protruding slightly into the water column. It feeds by filtering out suspended or resuspended material through short siphons at the sediment surface. This bivalve is considered less motile and functionally very different from the other species, but nevertheless is functionally representative of a large number of benthic animals. Its inclusion in the current study will provide a valuable comparison between the effect of mobile deposit-feeders and a less mobile suspension-feeder.

All the bioturbating species used during the current study are common within the study area (Oslofjord); however they also occur in many other areas throughout the North Sea, Irish Sea and English Channel, where fishing disturbance is absent or low. Where these precise species are not present it is not unusual to find closely related, functionally similar organisms in their place. The sediment and associated community selected for the experiment were from a wellbioturbated area that is subjected to relatively high levels of organic enrichment (Mirza \& Gray 1981). The benthic fauna of this area has been described as typical of that found in other sites in Western Europe and probably also of large areas of the European continental shelf (Mirza \& Gray 1981, Valderhaug \& Gray 1984). Consequently, the results and conclusions from the current study may have the potential to be applied to a large number of temperate, coastal areas in which fishing impact may occur.

Experimental set-up. The experiment was carried out in one of the benthic mesocosms of the NIVA (Norwegian Institute for Water Research) Marine Research Station, Solbergstrand, Oslofjord, Nor-

way. The mesocosm used is a $5 \times 7 \mathrm{~m}$ indoor, epoxy-resin-coated concrete basin in which a constant depth of 100 $\mathrm{cm}$ is maintained with a continuous flow of water pumped from $60 \mathrm{~m}$ depth from the Oslofjord. The system has been described in detail by Berge et al. (1986).

Using a Day grab, muddy sand was collected from $30 \mathrm{~m}$ depth in Bjørnehodebukta, a sheltered bay in the inner part of Oslofjord. This sediment was used to fill food-quality plastic buckets ( $36 \mathrm{~cm}$ diameter, surface area $=0.1 \mathrm{~m}^{2}$ ), to a depth of $30 \mathrm{~cm}$. It has been shown that soft-sediment communities can be patchy at scales greater than the area sampled by a single grab (Kendall \& Widdicombe 1999). Therefore, if each bucket had been filled with sediment from a single grab, a high level of dissimilarity between buckets would have occurred. By using the sediment from a number of different grabs to fill each bucket, this heterogeneity was reduced and ensured that each bucket had a similarly high number of species at the start of the experiment. As the sediment was added to the buckets, any conspicuous bioturbating species were removed. The buckets were placed in the mesocosm on 7 March 2002 and the sediment was allowed to settle for at least $2 \mathrm{~d}$. Into each bucket, 1 of 7 species of bioturbators was added at either high or low densities (Table 1). These densities were adjusted to actual published values for the natural field densities of each species. The high densities were representative of the maximum density recorded whilst the low densities were representative of the most commonly reported densities. These 14 'treatments' were each replicated 4 times with an additional 7 control buckets containing no bioturbators. Bioturbators were collected on the eastern side of Håøya Island, Oslofjord, during the period 8 to 16 March 2002. Most bioturbators were introduced to the treatment buckets within $24 \mathrm{~h}$ of collection.

After the bioturbators had been added, the experiment ran for $21 \mathrm{wk}$. The sediments and communities of Oslofjord receive a relatively large input of organic material during the summer months (Rosenberg et al. 1987). In order to reproduce these conditions within the mesocosm, each bucket received three $3.21 \mathrm{~g}$ doses of freeze-dried, powdered Entromorpha sp. algae ( $3.9 \% \mathrm{~N}$ and $31 \% \mathrm{C})$. These were added on 15 June, and on 5 and 26 July 2002.

Sampling. On 7 March 2002, 4 macrofauna 'field' samples were taken at the sediment collection site using a $0.1 \mathrm{~m}^{2}$ Day grab, and sieved over $0.5 \mathrm{~mm}$ mesh. The residue was preserved in $10 \%$ formaldehyde solution. On 17 March 2002, 3 of the 7 control buckets es-

Table 1. Treatment densities (individuals bucket ${ }^{-1}$ ) for each of the 7 bioturbating species. For number of individuals $\mathrm{m}^{-2}$ multiply treatment density by 10

\begin{tabular}{|llcc|}
\hline Bioturbator & Organism type & $\begin{array}{c}\text { Low } \\
\text { density }\end{array}$ & $\begin{array}{c}\text { High } \\
\text { density }\end{array}$ \\
\hline Nuculana minuta & Bivalve & 8 & 32 \\
Astarte sulcata & Bivalve & 3 & 12 \\
Brissopsis lyrifera & Heart urchin & 1 & 4 \\
Amphiura chiajei & Brittle star & 7 & 28 \\
Aphrodita aculeata & 'Sea mouse' polychaete & 1 & 4 \\
Nephtys caeca & Polychaete & 1 & 4 \\
Calocaris macandreae & Burrowing shrimp & 1 & 4 \\
\hline
\end{tabular}


tablished within the mesocosm were sampled to ascertain the macrofaunal diversity present in the buckets at the start of the experiment. The sediment from each bucket was preserved in $10 \%$ formaldehyde solution. By comparing these 'initial' samples with the 'field' samples taken from Bjørhodebukta, an assessment of how successfully the natural field communities were transplanted into the mesocosm system could be made.

Final sampling in the mesocosm took place from 9 to 14 August 2002. The sediment from each bucket was sieved over $0.5 \mathrm{~mm}$ mesh and the residue was preserved in $10 \%$ formaldehyde solution. During this sampling period, the initial samples collected and preserved in March were sieved and the residue was returned to $10 \%$ formaldehyde solution.

In the laboratory, all organisms contained within the residue were extracted under a binocular microscope and identified to the lowest possible taxonomic level. The numbers and identities of bioturbators in each bucket at the end of the experiment were noted and compared to the original number added to ascertain bioturbator survival and identify buckets contaminated by other species of bioturbator.

Data analysis. Number of species $(S)$, number of individuals (NI), Margalef species richness $(d)$ and Pielou's evenness $\left(J^{\prime}\right)$ were calculated for each sample using PRIMER (Plymouth routines in multivariate ecological research) v5.0. More than one measure of diversity was used in order to appreciate how bioturbation may act on a community. Measures of species richness ( $S$ and $d$ ) enable an evaluation of diversity change based on the number of species present whilst a measure of evenness $\left(J^{\prime}\right)$ indicates how the individual organisms are distributed amongst the species present. Statistical analyses of these indices were performed using MINITAB 13 for Windows computer package. Due to the survival rate of the bioturbating test species being less than 100\%, relationships between bioturbator abundance and the above indices were examined using linear regression analysis. Where visual interpretation indicated a potential nonlinear relationship, and sufficient replication allowed, pair-wise ANOVA was used to further explore the relationship.

Multivariate data analyses followed the methods described by Clarke (1993) using PRIMER v5.0. Analysis was carried out on both untransformed and presence/absence data, using the Bray-Curtis similarity measure, to determine the effects of treatments on different components of the community. Analysis of untransformed data is sensitive to changes in the abundance of the dominant species, whilst analysis of presence/absence data detects changes in community structure due to the identities of all the species present without being unduly influenced by dominant, high- abundance species. ANOSIM (analysis of similarities) (Clarke \& Warwick 2001) was carried out to test for treatment effects. Similarity percentages (SIMPER) analysis was used to identify the species responsible for any dissimilarity between different treatments (Clarke \& Warwick 2001).

\section{RESULTS}

\section{Impact of experimental set-up on macrofaunal diversity and community structure}

A summary of the diversity values for field, initial and control samples is shown in Table 2. For measures of species diversity, i.e. number of species $(S)$ and species richness $(d)$, no significant differences were observed between field and initial samples $(S: F=3.18$, $\mathrm{p}=0.135 ; d: F=5.79, \mathrm{p}=0.061)$ or between field and control samples $(S: F=4.69, \mathrm{p}=0.074 ; d: F=3.27, \mathrm{p}=$ 0.121). However, the species diversity of the control samples was significantly lower than that of the initial samples $(S: F=50.91, \mathrm{p}=0.001 ; d: F=33.25, \mathrm{p}=0.002)$. This indicates that a small, but insignificant, increase in species diversity occurred when the communities were established in the mesocosm and that species diversity in control treatments subsequently declined over the course of the experiment to a level equivalent or lower than that of naturally occurring field levels.

For number of individuals there were no significant differences for field versus initial $(F=0.77, \mathrm{p}=0.420)$ or initial versus control $(F=0.70, \mathrm{p}=0.441)$. No significant differences were observed for measures of evenness. Multivariate analysis (ANOSIM) demonstrated no significant differences between the community structure of the field and the initial samples, either in the relative abundance of the numerically dominant species (untransformed data; $\mathrm{R}=0.481, \mathrm{p}=0.057$ ) or in the identity of the rare species (presence/absence data; $\mathrm{R}=0.481, \mathrm{p}=0.086)$. Comparisons of the initial and control samples (ANOSIM) indicated that the mesocosm community did not change significantly over the course of the experiment in response to any factors other than those being deliberately manipulated

Table 2. Measures of diversity for field, initial and control samples (means $\pm 95 \% \mathrm{CI}$ )

\begin{tabular}{|lccc|}
\hline Parameter & Field & Initial & Control \\
\hline No. of species $(S)$ & $27 \pm 4.0$ & $31.3 \pm 0.6$ & $22 \pm 2.1$ \\
No. of individuals & $215 \pm 38.9$ & $189 \pm 61.8$ & $161 \pm 19.2$ \\
Species richness $(d)$ & $4.82 \pm 0.64$ & $5.85 \pm 0.45$ & $4.13 \pm 0.38$ \\
Evenness $\left(J^{\prime}\right)$ & $2.43 \pm 0.20$ & $2.60 \pm 0.09$ & $2.05 \pm 0.19$ \\
\hline
\end{tabular}


(untransformed data: $\mathrm{R}=0.037, \mathrm{p}=0.429$; presence/ absence data: $\mathrm{R}=0.278, \mathrm{p}=0.143$ ).

\section{Bioturbator survival and treatment integrity}

Of the 60 treatment buckets, 6 were discarded from the analyses as they contained a Calocaris macandreae individual in addition to the bioturbators constituting the expected bioturbator treatment. These treatments were 1 high-density Brissopsis lyriferas, 1 high-density Aphrodita aculeata, 1 high-density Amphiura chiajei, 2 lowdensity Astarte sulcata and 1 high-density A. sulcata. Observations from this study and previous experiments (Widdicombe \& Austen 2003) have indicated that it is not unusual for C. macandreae to leave treatment areas during the first few weeks of an experiment. After this time any shrimps still present tend to remain for the full duration of the experiment. Widdicombe \& Austen (2003) showed no significant difference in macrofauna commuity structure or diversity between the areas that had been abandoned by shrimps and control areas that had never contained shrimps. It is reasonable, therefore, to use the number of shrimps present at the end of the experiment as the true treatment condition. Due to the abandonment of buckets by 1 or more shrimps, the densities of shrimp in some of the C. macandreae treatments were reduced. This resulted in 5 control treatments, 3 treatments containing a single C. macandreae, 3 treatments with 2 C. macandreae and a single treatment containing $3 \mathrm{C}$. macandreae. The other bioturbator that displayed a notable loss from the treatment buckets was Nephtys caeca. This resulted in 6 treatments containing a single $N$. caeca and 2 treatments containing $3 N$. caeca. One B. lyrifera low-treatment bucket contained an additional N. caeca; this bucket was excluded from the analysis. No bioturbator losses were observed in the other treatments.

\section{Impact of bioturbating species on macrobenthic diversity and community structure}

Significant relationships between bioturbator abundance and species diversity ( $S$ and $d$ ) were observed for 3 species: Brissopsis lyrifera, Aphrodita aculeata and Amphiura chiajei (Fig. 1). For each of these species, the greater the abundance of bioturbators, the higher the species diversity of the associated fauna. For Nephtys caeca the relationship between bioturbator abundance and species diversity was not linear (Fig. 1). In the low-density treatments, species diversity was higher than in the controls. This difference was significant for species richness $(F=5.15, \mathrm{p}=0.05)$, but not for number of species $(F=4.13, \mathrm{p}=0.07)$. At the
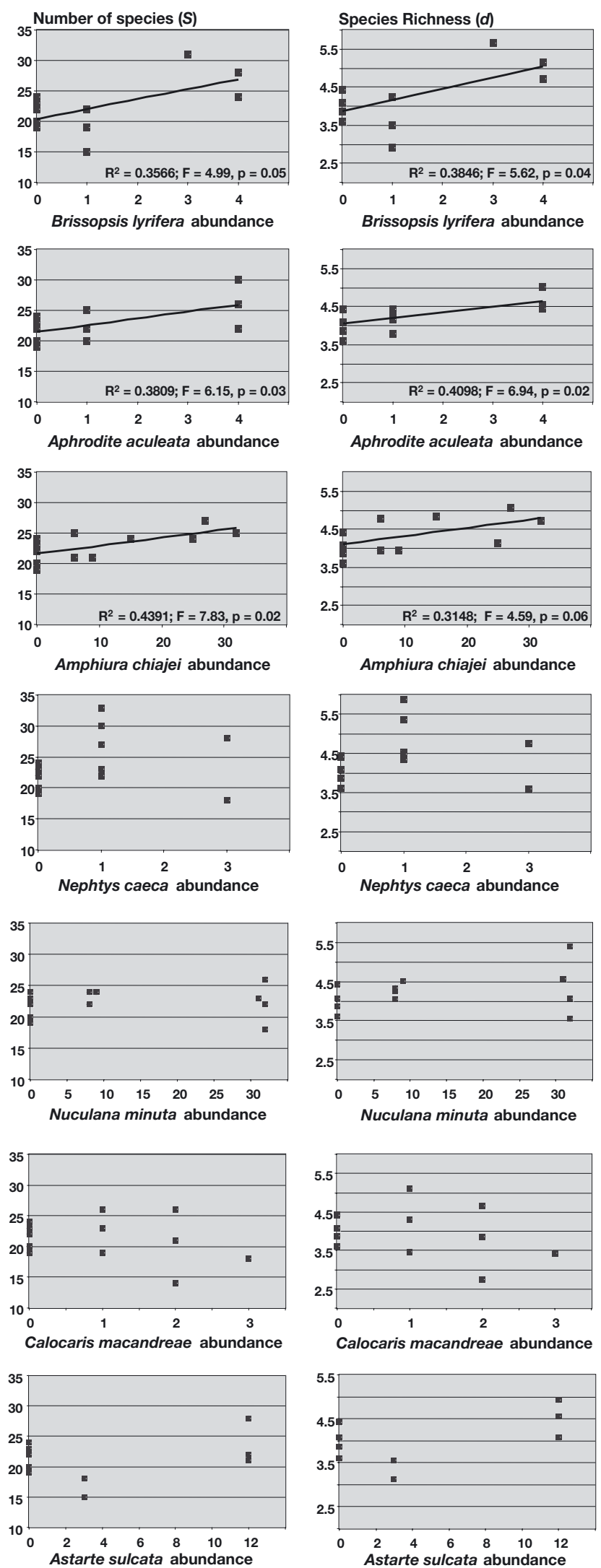

Fig. 1. Impact of bioturbator abundance on species diversity 
highest $N$. caeca density, species diversity appeared to fall back to a level similar to that of the controls. No significance testing could be performed for the highdensity treatments as there were only 2 replicates. No relationships were observed between species diversity and the abundance of Calocaris macandreae, Nuculana minuta or Astarte sulcata (Fig. 1).

No relationships were observed between the abundance of any of the bioturbating species and either Pielou's evenness or number of individuals (Fig. 2).

Multivariate analysis of both untransformed and presence/absence data failed to identify any patterns of community change in response to different bioturbator treatments.

\section{DISCUSSION}

This study has demonstrated that the presence of 4 bioturbating species, Brissopsis lyrifera, Aphrodita aculeata, Amphiura chiajei and Nephtys caeca, at densities equivalent to those observed in the field, had a significant, positive impact on the diversity of associated macrobenthic communities. Of these species, 3 (B. lyrifera, A. aculeata and N. caeca) are large, highly mobile organisms that actively move through the upper $10 \mathrm{~cm}$ of sediment in similar ways (Caron et al. 1996, Hollertz et al. 1998), and with respect to bioturbation these 3 species may be considered functionally similar. The type of movement these species employ has traditionally been termed 'bulldozing' and the species that operate in this way as 'bulldozers'. Whilst this definition is not a totally accurate representation of their locomotory behaviour it still offers a good shorthand description of the way in which they impact on their environment.

In areas such as Oslofjord, which receive high levels of organic input (Rosenberg et al. 1987), the high bacterial oxygen demand generated by microbial decomposers may have a negative impact on the macrofauna by lowering oxygen levels. However, by increasing the depth of oxygen penetration in organically enriched sediments, bioturbation can supply the additional oxygen required during the processing of the additional organic material (Aller 1994), thus reducing the impact of oxygen depletion on macrofauna species sensitive to low oxygen levels whilst also stimulating the activity of aerobic microbial decomposers and accelerating carbon processing. In addition, organic material buried within the deeper anoxic sediments degrades 3.6 times faster when re-exposed to oxic conditions than when left in anoxic conditions (Hulthe et al. 1998). Therefore, the physical mixing generated by bioturbators will facilitate this re-exposure and result in increased carbon degradation. A recent study by Widdicombe \&
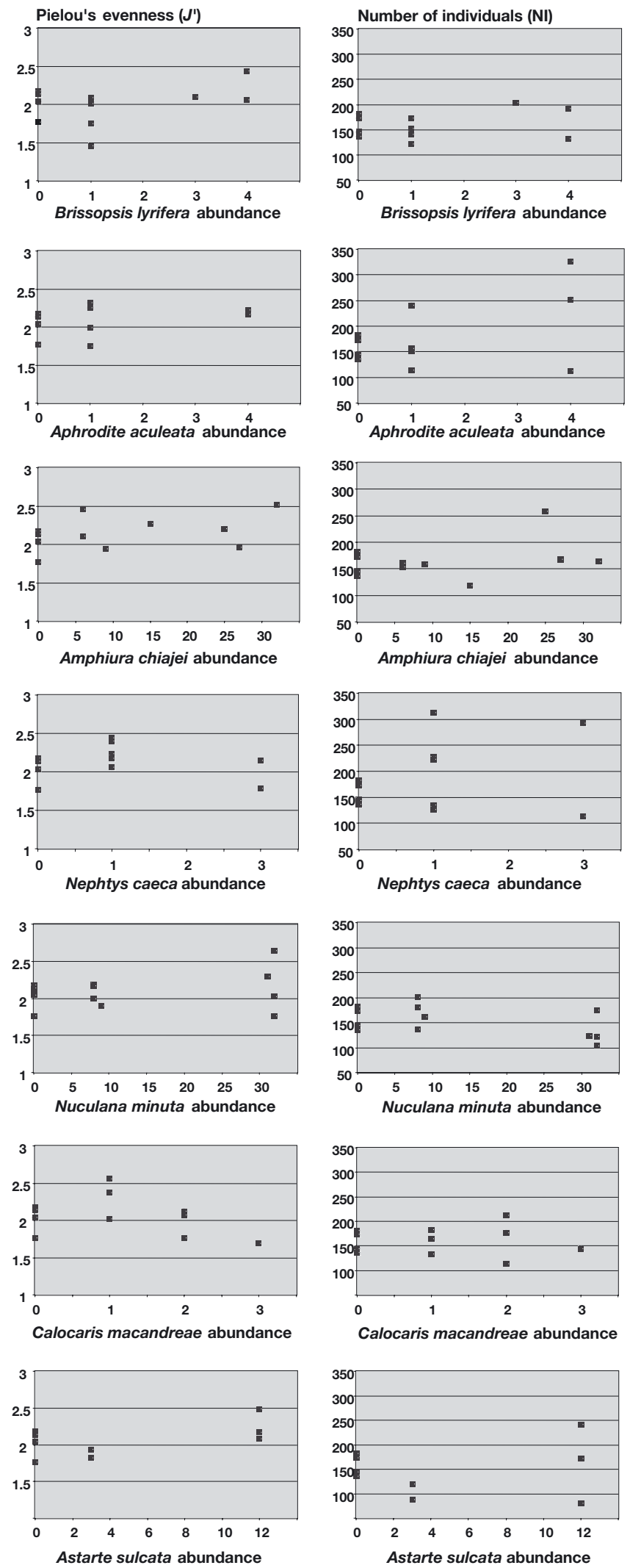

Fig. 2. Impact of bioturbator abundance on evenness diversity and faunal abundance 
Austen (2001) provided experimental evidence that a physical disturbance similar to bioturbation could maintain diversity in the presence of high organic input. The ameliorating effect of bioturbation by the polychaete Capitella capitata has even been shown to 'recondition' the organically polluted sediments that result from intensive aquaculture (e.g. Chareonpanich et al. 1994). It is not unreasonable to assume from the results of the current study and an appreciation of the species locomotory activities, that Brissopsis lyrifera, Aphrodita aculeata and Nephtys caeca may be enhancing diversity through this combination of oxygenation and sediment mixing.

The brittle star Amphiura chiajei buries its disk to a depth of $6 \mathrm{~cm}$ (Hollertz et al. 1998), resulting in increased oxygen penetration. Compared with the 3 'bulldozing' species (Brissopsis lyrifera, Aphrodita aculeata and Nephtys caeca) A. chiajei is less mobile and would therefore be unable to influence as large an area of sediment when present at similar densities. However, A. chiajei occurs at much greater densities than the other 3 species, and this was accounted for in the treatment densities used. The current study shows that the impact on diversity of B. lyrifera and A. aculeata at densities of 40 individuals $\mathrm{m}^{-2}$ was broadly equivalent to that of $A$. chiajei at densities of around 300 individuals $\mathrm{m}^{-2}$. So although A. chiajei is not a 'bulldozer', when present at realistic field densities it may still be responsible for increased sediment oxygenation and may be considered an important species in maintaining macrobenthic diversity.

The response of diversity to the presence of Nephtys caeca was different to that seen for Brissopsis lyrifera, Aphrodita aculeata or Amphiura chiajei. Increasing the density of $B$. lyrifera, $A$. aculeata and A. chiajei caused a linear increase in macrofaunal diversity, whilst the relationship between diversity and N. caeca was a 'humpback' curve. This 'humpback' relationship was similar to that described for B. lyrifera in a previous mesocosm experiment (Widdicombe \& Austen 1998). The fact that no decrease in diversity was seen in the current study for B. lyrifera may be due to the densities chosen. In the study by Widdicombe \& Austen (1998), the treatment densities were 28 and 71 individuals $\mathrm{m}^{-2}$ compared with the current study of 10 and 40 individuals $\mathrm{m}^{-2}$. It may be that between 40 and 71 individuals $\mathrm{m}^{-2}$ the negative impacts of sediment disturbance created by $B$. lyrifera become greater than the positive effects of increased oxygenation. Despite the current study demonstrating a positive, linear relationship between diversity and the abundance of both A. aculeata and A. chiajei, it should not be assumed that this relationship would be maintained indefinitely, and these species too may cause a decrease in diversity at densities greater than those used here.
Nephtys caeca and Aphrodita aculeata have both been described as active predators (Caron et al. 1996, Mettam 1980). It is important to consider the possible implications of this activity on the current study. Nonspecific deposit-feeders such as Brissopsis lyrifera may effectively be considered predators, as they indiscriminately consume small macrofaunal species through bulk ingestion of sediments. This non-selective predation has the potential of increasing diversity by reducing competitive exclusion (Widdicombe \& Austen 1998). However, predation that is targeted towards specific prey species, as it is the case for $N$. caeca and A. aculeata, may have 1 of 2 outcomes, depending on the identity of the prey species. Predation may result in the extinction of the prey species and a subsequent reduction in diversity (this may be of particular relevance in closed mesocosm systems) or, if the target species is a competitive dominant within the community, diversity may increase, as it does through nonselective predation. Polychaetes from the family Nephtydidae are reported to target many different prey species (Clark 1962, Beukema 1987) with $N$. caeca consuming mainly small polychaetes and crustaceans (Caron et al. 1995, 1996). It seems likely that some of the reduction in diversity observed in the high-density $N$. caeca treatments may have been due to predation on particular species of small polychaetes. Additionally, species such as the capitellid Heteromastus filiformis, a known prey species of $N$. caeca, were numerically abundant in the current study, and consequently any process that reduces their abundance may have an impact on diversity through competition. The diet of $A$. aculeata is more specialised than that of $N$. caeca, with $A$. aculeata preying mostly on large active polychaetes such as Nephtys spp. and Nereis spp. (Mettam 1980). These species are rare within the mesocosm system, and therefore the impact on diversity of predation by A. aculeata may be less than any impact due to bioturbation. In field sediments where $N$. caeca and $A$. aculeata co-occur implications of their interaction should also be considered. A. aculeata predation may reduce the abundance of $N$. caeca and consequently N. caeca's impact on other species. Also, the potential relationship between $N$. caeca and A. aculeata and the subsequent consequences for diversity may be heavily influenced by the relative impact of trawling disturbance on these 2 species. $N$. caeca is a deep-burrowing species and will be less affected by disturbances at the sediment surface. In contrast, A. aculeata operates at or near the sediment surface and will be vulnerable to damage from most types of benthic fishing gear (Kaiser et al. 1998). Resilience of $N$. caeca to fishing disturbance may also be high, compared to other types of bioturbator, because it is able to regenerate lost body tissue. 
The current study failed to demonstrate an effect on diversity resulting from the presence of Nuculana min$u t a$, and this may in part be due to the treatment densities chosen for this experiment. A previous experiment by Widdicombe \& Austen (1999) demonstrated a 'humpback' relationship between a similar species (Nuculoma tenuis) and diversity, with highest diversity occurring at bivalve densities of 612 individuals $\mathrm{m}^{-2}$. This density is almost double that of the highest treatment density used in the current study. It is therefore possible that, even though $N$. minuta is functionally similar to other mobile deposit-feeders, its small size means that in order to impact on diversity it needs to be present in much higher numbers. As the densities used in the current study were representative of naturally occurring field densities in Oslofjord, the actual densities required before $N$. minuta functions as an ecosystem engineer probably only occur under exceptional circumstances. In other habitats, such as physically controlled glacial bays, nuculid bivalves can be extremely abundant (1500 to 3000 individuals $\mathrm{m}^{-2}$ ), and are the numerically dominant species (Kendall \& Aschan 1993, Kendall et al. 2003); they thus may have a greater importance in these areas.

Astarte sulcata is a suspension-feeding bivalve and, as such, may be considered functionally different from the other species examined in this study. It was, therefore, not unexpected that an organism with such limited potential for bioturbation displayed no significant affect on diversity. This result supports the findings of Widdicombe \& Austen (1999), who observed that the presence of Abra alba, another suspension-feeding bivalve, also had no beneficial effects on diversity. The 'non-response' in A. sulcata treatments in this study and the observations on $A$. alba in the previous study of Widdicombe \& Austen (1999) highlights the importance of bioturbation, as opposed to the consumption of organic material, for maintaining diversity in areas of high organic input such as Oslofjord.

No enhancement of diversity was observed in treatments that contained Calocaris macandreae compared with the controls. This result is in partial agreement with a previous study (Widdicombe \& Austen 2003), which showed that despite having a significant effect on community structure C. macandreae had no significant effect on diversity. These results may appear surprising considering the extensive burrow construction and the resulting oxygenation of deep sediments associated with C. macandreae. However, unlike Brissopsis lyrifera, Aphrodita aculeata, Nephtys caeca and Amphiura chiajei, which all operate in the upper $10 \mathrm{~cm}, C$. macandreae lives within a burrow and generally operates much deeper, so any organic material that is supplied to the sediment surface will not be actively mixed into this layer as it is with the other bioturbators. From the current study it would appear that bioturbation associated with burrow formation is less important for maintaining diversity than the bioturbation of 'bulldozing' species, a conclusion also reached by Thayer (1983) who stated that 'biological bulldozing is the most effective form of bioturbation'.

By reducing the abundance of the large bioturbating species, trawling will have a long-lasting, indirect impact on the rest of the benthic fauna. Additionally, in areas that frequently become eutrophicated, such as Oslofjord (Rosenberg et al. 1987), the impact of losing key bioturbating species on benthic diversity could be exacerbated. It is important therefore that when considering the potential effects of anthropogenic impacts it is done in a holistic way rather than by considering the different impacts in isolation from each other.

In field observational studies it is often impossible to disentangle the direct and indirect effects of trawling. To demonstrate cause and effect and to distinguish treatment effects from confounding influences, controlled manipulative experiments are necessary. Mesocosms are well suited to such experiments as long as the results they produce are considered subject to the usual caveats. In particular, isolation from many of the influences that maintain community structure and function in the field, particularly the supply of recruits to replace dead and dying individuals, can be seen as compromising the extent to which results from mesocosm experiments can be applied to natural situations. In the current study, however, the method of sediment collection meant that the diversity within each bucket was higher than that found in corresponding areas of natural sediment. This enabled the study to examine whether bioturbation was necessary to maintain levels of diversity, rather than needing to observe an increase in diversity to demonstrate an effect. Now that an effect has been demonstrated, it is important that its relevance to natural situations is validated through field experiments, e.g. the reintroduction of bioturbators into areas where heavy trawling has reduced their numbers.

A surprising outcome of the current study was the failure of multivariate data analysis to identify any changes in macrobenthic community structure in response to different bioturbator treatments despite the fact that univariate measures of diversity clearly showed a response. This is all the more surprising as many authors have shown multivariate techniques to be extremely sensitive to community change, and able to detect underlying differences between groups that are undetectable by univariate techniques (Warwick \& Clarke 1991). To understand why this was not the case in the current study we must consider the different ways in which multivariate and univariate techniques identify differences between groups of samples. In the 
case of univariate measures, the identity of the species is of limited importance; 2 groups will be considered the same if they both contain the same number of species irrespective of whether they have any species in common or not. For multivariate analysis, however, species identity is critical, with differences between groups being affected not only by the number but also by the type of organisms present. This is particularly important when testing for significant differences between groups, as the sensitivity of the ANOSIM procedure is greatly affected by the degree of dissimilarity within the groups being compared. In the initial set-up for the current mesocosm experiment, the natural variability in species identity and composition of the field community was homogenised by ensuring that each bucket was filled using sediment from several different grabs. However, the identity of these species was not necessarily the same within each bucket, particularly for the less abundant species which would not be regularly distributed between treatments. This meant that whilst the set-up technique was appropriate for an experiment that intended to observe changes in species diversity, identity-dependent measures of community structure could be subjected to too much within-treatment dissimilarity to be able to identify between-treatment differences.

From the results of the current study, it can be concluded that Brissopsis lyrifera, Aphrodita aculeata, Amphiura chiajei and Nephtys caeca are important for the maintenance of macrobenthic diversity, and may be fulfilling the same role within the benthic ecosystem. Does it matter, therefore, if the majority of these species are lost, as long as at least 1 representative of this particular functional type remains? Also, what are the implications for diversity of the inevitable interactions that will occur between co-existing bioturbating species? As yet we do not know the answer to these questions, and only through carefully constructed experiments that combine different numbers and types of bioturbators from the same functional group will we be able to examine the role bioturbator diversity plays in the relationship between bioturbation and species diversity.

Acknowledgements. This study was funded in part by the EU FP5 project COST-IMPACT and by UK DEFRA (project no. AE1137). The work is also a contribution to the Plymouth Marine Laboratory's NERC funded core program (Aim 4: Biodiversity and Ecosystem Function). The authors would like to thank the following for their contributions and advice during the course of this study: Dr. K. R. Clarke (experimental design and statistical analysis), Dr. S. Jennings (choice of megafaunal species vulnerable to fishing), Dr. Aleksander Drgas (practical assistance whilst harvesting the experiment), Oddbjørn Pettersen, Per Ivar Johhannsen and Sigurd Øksnevad (technical support at the Solbergstrand Marine Station); and the crew of RVs 'Trygve Braarud' and 'Bjørn Føyn' (collection of sediment and bioturbators).

\section{LITERATURE CITED}

Aller RC (1994) Bioturbation and remineralization of sedimentary organic matter: effects of redox oscillation. Chem Geol 114:331-345

Berge JA, Schaanning M, Bakke T, Sandøy K, Skeie GM, Ambrose Jr WG (1986) A soft-bottom sublittoral mesocosm by the Oslofjord: description, performance and examples of application. Ophelia 26:37-54

Beukema JJ (1987) Influence of the predatory polychaete Nephtys hombergii on the abundance of other polychaetes. Mar Ecol Prog Ser 40:95-101

Buchanan JB (1964) A comparative study of some of the features of the biology of Amphiura filiformis and Amphiura chiajei (Ophiuroidea) considered in relation to their distribution. J Mar Biol Assoc UK 44:565-576

Buchanan JB (1967) Dispersion and demography of some infaunal echinoderm populations. Symp Zool Soc 20:1-11

Caron A, Boucher L, Desrosiers G, Retiere C (1995) Population dynamics of the polychaete Nephtys caeca in an intertidal estuarine environment (Quebec, Canada). J Mar Biol Assoc UK 75:871-884

Caron A, Desrosiers G, Retiere C, Brenot S (1996) The behaviour of Nephtys caeca inside sediment under experimental conditions. C R Acad Sci Sér III Sci Vie Sci 319:417-423

Chareonpanich C, Tsutsumi H, Montani S (1994) Efficiency of the decomposition of organic matter, loaded on the sediment, as a result of the biological activity of Capitella sp. I. Mar Pollut Bull 28:314-318

Clark RB (1962) Observations on the food of Nephtys. Limnol Oceanogr 7:380-385

Clarke KR (1993) Non-parametric multivariate analyses of changes in community structure. Aust J Ecol 18:117-143

Clarke KR, Warwick RM (2001) Changes in marine communities: an approach to statistical analysis and interpretation, 2nd edn. National Environmental Research Council, Cambridge, UK

Craeymeersch JA, Heip CHR, Buijs J (1997) Atlas of North Sea benthic infauna. Int Counc Explor Sea Coop Sci Rep 218:86 pp

De Groot SJ, Lindeboom HJ (1994) Environmental impact of bottom gears on benthic fauna in relation to natural resources management and protection of the North Sea. Rep 1994-11. Netherlands Institute for Fisheries Research, Texel

De Ridder C, Lawrence JM (1982) Food and feeding mechanisms: Echinoidea. In: Jangoux M, Lawrence JM (eds) Echinoderm nutrition. AA Balkema, Rotterdam, p 57-115

Fenaux L (1970) Maturation of the gonads and seasonal cycle of the planktonic larvae of the ophiuroid Amphiura chiajei Forbes. Biol Bull (Woods Hole) 138:262-271

Frid CLJ, Clark RA, Hall JA (1999) Long term changes in the benthos of a heavily fished ground off the NE coast of England. Mar Ecol Prog Ser 188:13-20

Hill AS, Brand AR, Wilson UAW, Veale LO, Hawkins SJ (1996) Estimation of by-catch composition and annual by-catch mortality on Manx scallop fishing grounds. In: Greenstreet SPR, Tasker ML (eds) Aquatic predators and their prey. Blackwell Scientific Publications, Oxford, p 111-115

Hollertz K, Sköld M, Rosenberg R (1998) Interactions between two deposit feeding echinoderms: the spatangoid Brissopsis lyrifera (Forbes) and the ophiuroid Amphiura chiajei Forbes. Hydrobiologia 375/376:287-295

Hulthe G, Hulth S, Hall POJ (1998) Effects of oxygen on degradation rate of refractory and labile organic matter in continental margin sediments. Geochim Cosmochim Acta 62:1319-1328 
Jennings S, Kaiser MJ (1998) The effects of fishing on marine ecosystems. Adv Mar Biol 34:201-352

Jennings S, Nicholson MD, Dinmore TA, Lancaster JE (2002) Effects of chronic trawling disturbance on the production of infaunal communities. Mar Ecol Prog Ser 243:251-260

Kaiser MJ, Hill AS, Ramsay K, Spencer BE and 7 others (1996) Benthic disturbance by fishing gear in the Irish Sea: a comparison of beam trawling and scallop dredging. Aquat Conserv: Mar Freshw Ecosyst 6:269-285

Kaiser MJ, Edwards DB, Armstrong PJ, Radford K, Lough NEL, Flatt RP, Jones HD (1998) Changes in megafaunal benthic communities in different habitats after trawling disturbance. ICES J Mar Sci 55:353-361

Kendall MA, Aschan M (1993) Latitudinal gradients in the structure of macrobenthic communities: a comparison of Arctic, temperate and tropical sites. J Exp Mar Biol Ecol 172:157-170

Kendall MA, Widdicombe S (1999) Small scale patterns in the structure of macrofaunal assemblages of shallow soft sediment. J Exp Mar Biol Ecol 237:127-140

Kendall MA, Widdicombe S, Weslawski JM (2003) A multiscale study of the biodiversity of the benthic infauna of the high latitude Kongsfjord, Svalbard. Polar Biol 26:383-388

Lawrence J (1987) A functional biology of echinoderms. John Hopkins University Press, Baltimore

Mettam C (1980) On the feeding habits of Aphrodita aculeata and commensal polynoids. J Mar Biol Assoc UK 60: 833-834

Mirza FB, Gray JS (1981) The fauna of benthic sediments from the organically enriched Oslofjord, Norway. J Exp Mar Biol Ecol 54:181-207

Munday BW, Keegan BF (1992) Population dynamics of Amphiura chiajei (Echinodermata: Ophiuroidea) in Killary Harbour on the west coast of Ireland. Mar Biol 114:595-605

Nash RDM, Chapman CJ, Atkinson RJA, Morgan PJ (1984) Observations on the burrows and burrowing behaviour of Caocaris macandreae (Crustacea: Decapoda: Thalassinoidea). J Zool 202:425-439

Nichols D (1959) Changes in the chalk heart-urchin Micraster interpreted in relation to living forms. Phil Trans R Soc B 242:347-437

Posey MH (1986) Changes in a benthic community associated with dense beds of a burrowing deposit feeder, Callianassa californiensis. Mar Ecol Prog Ser 31:15-22

Posey MH, Dumbauld BR, Armstrong DA (1991) Effects of a burrowing mud shrimp, Upogebia pugettensis (Dana), on abundances of macro-infauna. J Exp Mar Biol Ecol 148: 283-294

Rijnsdorp AD, Buijs AM, Storbeck F, Visser E (1998) Microscale distribution of beam trawl effort in the southern

Editorial responsibility: John Gray (Contributing Editor), Oslo, Norway
North Sea between 1993 and 1996 in relation to the trawling frequency of the seabed and the impact on benthic organisms. ICES J Mar Sci 55:403-419

Rosenberg R, Gray JS, Josefson AB, Pearson, TH (1987) Petersen's benthic stations revisited. 2. Is the Oslofjord and eastern Skagerrak enriched? J Exp Mar Biol Ecol 105: 219-251

Thayer CW (1983) Sediment-mediated biological disturbance and the evolution of marine benthos. In: Tevesz MJS, McCall PL (eds) Biotic interactions in recent and fossil benthic communities. Plenum Press, New York, p 479-625

Tupper M, Boutilier RG (1995) Effects of habitat on settlement, growth and postsettlement survival of Atlantic cod (Gadus morhua). Can J Fish Aquat Sci 52:1834-1841

Valderhaug VA, Gray JS (1984) Stable macrofauna community structure despite fluctuating food supply in subtidal soft sediments of Oslofjord, Norway. Mar Biol 82:307-322

Warwick RM, Clarke KR (1991) A comparison of some methods for analysing changes in benthic community structure. J Mar Biol Assoc UK 71:225-244

Warwick RM, Gee JM, Berge JA, Ambrose W Jr (1986) Effects of the feeding activity of the polychaete Streblosoma bairdi (Malmgren) on meiofaunal abundance and community structure. Sarsia 71:11-16

Warwick RM, Clarke KR, Gee JM (1990) The effect of disturbance by soldier crabs, Mictyris platycheles $(\mathrm{H}$. Milne Edwards), on meiobenthic community structure. J Exp Mar Biol Ecol 135:19-33

Widdicombe S, Austen MC (1998) Experimental evidence for the role of Brissopsis lyrifera (Forbes, 1841) as a critical species in the maintenance of benthic diversity and the modification of sediment chemistry. J Exp Mar Biol Ecol 228:241-255

Widdicombe S, Austen MC (1999) Mesocosm investigation into the effects of bioturbation on the diversity and structure of a subtidal macrobenthic community. Mar Ecol Prog Ser 189:181-193

Widdicombe S, Austen MC (2001) The interaction between physical disturbance and organic enrichment: an important element in structuring benthic communities. Limnol Oceanogr 46:1720-1733

Widdicombe S, Austen MC (2003) The effects of bioturbation by the burrowing shrimp Calocaris macandreae on a subtidal macrobenthic community: further evidence for the importance of function over identity. Vie Milieu 53:163-170

Widdicombe S, Austen MC, Kendall MA, Warwick RM, Jones MB (2000) Bioturbation as a mechanism for setting and maintaining levels of diversity in subtidal macrobenthic communities. Hydrobiologia 440:369-377

Submitted: January 16, 2004; Accepted: March 12, 2004

Proofs received from author(s): June 15, 2004 